\title{
Does Religiosity Affect Multidimensional Poverty? Evidence from World Values Survey (2010-2014)
}

\author{
Salman Syed Ali \\ Senior Economist, Islamic Research and Training Institute, \\ Islamic Development Bank, Jeddah, Saudi Arabia \\ Hamid Hasan \\ Assistant Professor, International Institute of Islamic Economics, \\ International Islamic University Islamabad, Pakistan
}

ABSTRACT. Based on macro-level observations that high religiosity is associated with lower economic growth, it is generally assumed that religiosity contributes to poverty. However, this conjecture may not be true because religion provides motivation to the poor, encourages cooperation in society, and influences preferences and habits in ways that could help reduce poverty. The present paper uses data from World Values Survey (WVS) covering 52 countries and 74,042 individuals, to construct a measure of multidimensional poverty based on deprivation counting approach and a measure of religiosity based on faith deprivation. It then addresses three questions: (a) Is religiosity similar among multidimensional-poor and non-poor? (b) Are there any differences in dimensions of deprivations among high religiosity and low religiosity people? (c) What is the impact of religiosity on multidimensional poverty? It finds that higher religiosity is associated with lower multidimensional poverty; faith-poor are more deprived in their protections of intellect and posterity than protections of life and wealth. A decrease in religiosity increases multidimensional poverty. An implication of the study is that a religious society would be less poor even if its economic growth is slow.

Keywords: Religion, Maqāșid al-Sharī‘ah, Poverty, Multidimensional poverty, Religiosity.

JEL Classification: N30, Z12

KAUJIE Classification: B5, H47, N5 


\section{Introduction}

Does religiosity affect multidimensional poverty? There is no simple answer to this question because there is no simple relationship between poverty and religiosity. Poverty is affected by religion in so many different ways, positively and negatively, through different routes and channels, that no plain general argument can be built. Yet, it is a fact that poverty, and its feel to the people, is indeed affected by religion and religiosity of the people. In its influence and impact, the content of the religion as well as the practice of its followers greatly matter. The core beliefs, and the core dos and don'ts, form the content of a religion along with its substance. It would be interesting to analyze how the content of different religions would differently affect poverty.

However, the current state of research has not reached that stage yet. Even some more basic questions need to be answered that have not been studied and that could lead to improved understanding and open new avenues for further research. For example, we do not know whether the poor and non-poor are equally religious. We understand that poverty is multidimensional, that it is not only in income and wealth but also in other dimensions important for human life. In this case, what dimensions should matter? How the patterns of deprivation across these various dimensions differ between the religious and nonreligious multidimensional-poor and what impact religiosity makes on multi-dimensional poverty?

The present paper attempts to provide first cut answers to these questions. It relies on publicly available data that can provide proxy measures for concepts of religiosity and multidimensional poverty. While more proper answers would require a purpose-made survey, collecting pertinent information to quantify religiosity as well as poverty in multiple key dimensions. Until then, we make use of the available data. To put things in perspective, and understand the gaps in literature, a succinct review is provided in section 2. Section 3 spells out the key questions. Our methodology and data is described in section 4. Analysis and core results of this paper are given in section 5 . Lastly, section 6 concludes the paper.

\section{Literature Survey}

Literature on economics and religion is extensive and growing. This is evidenced through extensive surveys by Iannaccone (1998), Jackson and Fleischer (2007), and Iyer (2016) that have appeared over the past two decades.

While a considerable number of studies deal with religiosity and economic development (Barro \& McCleary, 2003; Bettendorf \& Dijkgraaf, 2010; Crabtree, 2010; Herzer \& Strulik, 2017; Yusof, Budiman, \& Amin, 2018; Ruck, Bentley, \& Lawson, 2018), comparatively little is available on poverty and religion. The literature on religion and economic development usually brings out a negative relationship between religiosity and economic development. The relation between religiosity and poverty is not known but guessed to be the same. In the following three sub-sections we give a short survey of literature on the above two aspects and on the role of religion in poverty alleviation.

\subsection{Religion and Economic Development}

It is generally observed that the people in third world countries, compared to the economically developed countries, show more religiosity while the countries are relatively poor. Crabtree (2010) thus titled his findings 'Religiosity Highest in World's Poorest Nations'. Providing the analysis in Gallup News, he writes:

Each of the most religious countries is relatively poor, with a per-capita GDP below $\$ 5,000$. This reflects the strong relationship between a country's socioeconomic status and the religiosity of its residents. In the world's poorest countries - those with average per-capita incomes of $\$ 2,000$ or lower - the median proportion who say religion is important in their daily lives is $95 \%$. In contrast, the median for the richest countries - those with average per-capita incomes higher than $\$ 25,000$ - is 47\%. (Crabtree, 2010, para 2)

This observation can lead to the conclusion that religiosity is associated with poverty. Arguments given by Marx (1843) that religion is "the opium of the people"(1), and the ideas propagated by atheists and even some secular economists allude to this line of

(1) Marx stated: "Religion is the sigh of the oppressed creature, the heart of a heartless world, and the soul of soulless conditions. It is the opium of the people" (Marx, 1843, para 4). 
thinking. For example, Wiseman and Young (2014) used cross-sectional US state-level data to investigate the relationships between measures of religiosity and levels of entrepreneurial activity. They find that "several religious variables significantly and negatively correlate with a state's productive entrepreneurship score" and that "the percent of individuals reporting as atheist/agnostic is positively associated with productive entrepreneurship" (p. 21). Similarly, Herzer and Strulik (2017) show that there exists a negative long-run relationship between the level of religiosity, measured by church attendance, and the level of income growth, measured by the log of GDP per capita. However, Guiso, Sapienza, and Zingales (2002) note that "on average, religious beliefs are associated with "good" economic attitudes, where "good" is defined as conducive to higher per capita income and growth" (p. 1).

More recently Ruck et al., (2018) examined the relationship between secularization (defined as decline in religion) and economic development (defined by GDP per capita). They created a long timeseries data of religiosity and then used this data to conclude that the religious decline preceded economic growth in most countries. Their study rules out reverse causality from economic development to secularization by assuming that individuals' religiosity is developed during their formative age and carries over. So, if any correlation existed between religiosity and GDP per capita in the future years, it cannot be due to income effecting religiosity. They further pinned the driver of development to the rise of secular norms of tolerance and attitudes toward divorce, homosexuality, and liberal values.

In general, these papers are about reinstatement of secularization hypothesis, i.e., how pervasive religion is as countries become richer. This hypothesis posits that economic development by increasing education, urbanization, and making available alternate arrangements for economic and social security, leads to lower religiosity. In other words, it associates irreligiosity and secularization as a requirement for development.

\subsection{Religion and Poverty}

There is comparatively small literature on religiosity and poverty. The analysis of how religion, its values, and religiosity, can influence poverty has not been taken up to the same extent. This is despite the fact that religions are usually clear about the values they support, and clarity of values help in creating testable hypotheses. Part of the problem is in the abstraction of the concept of religiosity and a greater part of the problem is in the unavailability of data. One empirical study on the relationship between poverty and religion, albeit in the context of Britain, is by Heath and $\mathrm{Li}$ (2015) that uses UK Longitudinal Household Panel Study (also known as Understanding Society Usoc) and finds differential incidence of poverty among different religious groups after controlling for differences in ethnicity and other factors. This too is only a report on one country, essentially separating poverty among different faith groups, Muslims, Sikhs, Hindus, Christians, and people with no religion. It looks at income poverty only. The intent of the report was to see how the immigrants belonging to different religious groups have adjusted, or not adjusted, in the British economic and social milieu.

A recent study by Yusof et al. (2018) is somewhat closer to ours. However, it focuses on the relationship between religiosity and wellbeing, not poverty. Collecting primary survey data from 461 respondents in South Kalimantan, Indonesia, it creates a multidimensional measure of Islamic religiosity by combining ritualistic, experiential, ideological, consequential and intellectual aspects of religion. The study finds that the more religious and more educated people are relatively better-off than the others in South Kalimantan.

\subsection{Role of Religion in Poverty Alleviation}

Before moving further in some organized way in context of the present study on religiosity and poverty, we need to understand that the role of religion is quite diverse in relation to poverty (Beyers, 2014). However, in tackling poverty, the role of religion can be divided into three operating channels:

(a) Soothing or functional role of religion, as it provides psychological help to the poor in coping with the difficulties of poverty.

(b) The attention giving and poverty alleviation role of religion as it encourages others to help the poor or it creates institutions to help the poor.

(c) The development and incentivizing role, as religion encourages the poor to exert themselves actively to come out of poverty. The religion also 
helps in inculcating behaviors and developing preferences and habits that save the people from falling into the poverty trap.

All these factors affect the behavior of the poor and non-poor in the society individually and collectively.

Mostly, the conventional economics literature on religion and poverty takes only the first listed functional role of religion. That is, people rely more on religion when poor because it provides solace, an idea of comfort in destiny, and gives them another dimension to consider and maximize, which is the after-life. In essence, this strand of literature attempts to explain religiosity as a function of poverty rather than poverty as a function of religiosity.

The literature in this strand points out that the higher mean personal religiosity tends to be associated with worse 'social environments'. It conjectures a possible reason for this in that the exposure to stressful situations (i.e. personal insecurity) increases personal religiosity. Norris and Ingelhart (2004) and Rees (2009) are two examples.

Norris and Ingelhart (2004) find a strong positive correlation between income inequality and religiosity in a multinational panel. Since the distribution of wealth differs across nations even when they have similar average wealth and similar material advancement, hence, they argue that it may be the inequality that is a determinant of cross-national differences in religiosity. Rees (2009) uses income inequality (as a proxy for personal insecurity) and religiosity (operationalized as the mean frequency of prayer) to get similar results. He finds importance of personal insecurity as a driver of religiosity along with other national-scale determinants of religiosity.

The other two roles listed above in $\mathrm{b}$ (the attention giving role of religion) and $\mathrm{c}$ (the incentivizing role of religion) are often ignored in the economics literature.

The literature on $z a k \bar{a} h$ in the context of Islamic finance takes up the $2^{\text {nd }}$ role to some extent (i.e. providing attention and channeling other peoples' help to the poor) as it analyzes the role of zakāh (an obligatory religious charity) in poverty alleviation. It sheds light on the consideration for others and the role of religion in obligating and encouraging others to help the poor by individual efforts as well as by creating state institutions for this purpose. The literature on charity and $a w q \bar{a} f$ also falls in this category as charity and giving (sadaq $\bar{a} t$ ) is not obligatory but encouraged by religious teachings. Religion also promotes considerate behavior towards poor.

Closer to the incentivizing role of religion (the $3^{\text {rd }}$ channel), but with a slightly different angle, is the literature that discusses how religion or religious beliefs influence opinions about ways people become poor. Norcia and Rissotto (2013) is an example of how religion through individuals' attributions influences poverty. The policy implications of this literature would be to influence individuals' attributes through religion in order to influence poverty.

From the discussion in the above sections it is now clear that the literature has primarily discussed religion and development, religion and well-being, and religion and inequality but little on religion and poverty. To the extent the literature on religion and poverty exists, it has either asked the reverse question that how religiosity is determined by poverty or it has focused only on income poverty.

\section{Objective and Key Questions}

The present paper is not concerned with the rationalization of religion in economic decision making or modelling the religious behavior. Rather, its focus is on poverty and its relationship to religiosity. It builds form data on individual level behavior to arrive at macro-level conclusions. The paper asks very simple but important questions:

Q1. Is religiosity similar among multidimensionalpoor and non-poor?

Q2. Are the poor among the religious people different in their deprivations from the poor among non-religious people? That is, are there any differences in dimensions of deprivations among high religiosity and low religiosity people?

Q3. What is the impact of religiosity on multidimensional poverty?

These are not just issues of curiosity but hold importance both from academic and policy perspectives. Answers to these questions will educate us whether poverty is an inseparable aspect of religiosity or not. It will provide evidence-based understanding whether societies can achieve socio-economic development while being religious. It can also potentially provide policy guidance on which deprivations matter for multidimensional poverty alleviation in religious and non-religious societies. 
However, to proceed with answering these questions requires a working-definition of religiosity and also a definition of religious and non-religious people. These are defined in the next section. The paper provides analysis using individual level data and controlling for fixed country effects and other possible influences.

Moving forward, there are several possibilities of relationship between religiosity and poverty. Either religion is causing poverty, hence, a cause of underdevelopment; or poverty is giving rise to religiosity, a concern in the present global context; or there is a bidirectional relationship each re-enforcing the other which would require causality analysis. However, in this paper we are mainly concerned with correlations only and to some extent with the first possibility i.e., the impact of religion on poverty. Even in this simplified form, the analysis of the relationship can pose significant issues. For example, the existence of association between poverty and religiosity analyzed in this way may not be correct because poverty can be a consequence of a number of country specific factors, such as poor governance, prevalence of injustice, or it may be due to natural factors that vary across countries. The differences that are found across countries in this relationship could be due to differences in these observed and unobserved factors that are affecting both; thus, creating a spurious relationship between high religiosity and poverty. We need to devise a strategy to control for these.

We proceed by first analyzing if there is any relationship between poverty and religiosity. To disentangle and control for the possible spurious effects we use ungrouped and grouped-by-country data. The model is estimated using all individual level observations using data from World Values Survey (WVS) wave- 6 (this is the ungrouped analysis). Then the analysis was repeated with data separated by countries (this is the grouped analysis). This within country analysis using individual level data has the advantage that, to a great extent, it automatically controls for country specific effects. For example, weak governance, prevalence of injustice, other natural factors, etc., will be equally affecting poor and non-poor in a given country.
Another key aspect to note is that, poverty is not simply of income or lack of material things such as food, shelter, and clothing. Poverty is multidimensional in existence as well as in feeling. Cognizance of multifaceted poverty has given rise to the Human Development Index (HDI) and the Multidimensional Poverty Index (MPI). The HDI uses health, education and income aspects while the MPI uses health, education, and standard of living dimensions to define poverty. However, these indices still focus on material things and at most on three dimensions that have been arbitrarily selected given the available data. It is also hard to arrive at a common understanding of which dimensions matter most for the measurement of development and, by its reverse image, the measurement of poverty.

We abstract away from human thinking and take some key protections, which are enjoined by divine Islamic law, as the necessary dimensions that should be guarded for human welfare. This is referred to as maqāșid al-Sharīah, i.e., the objectives of Islamic law. Al-Juwayni [d.1085], al-Ghazali [d.1111], and al-Shatibi [d.1388] were among the earliest articulators of these objectives. They identified safeguarding of faith, human self, human intellect, progeny, and wealth of individual and society as the primary objectives of the divine law (for details, see: al-Ghazali, 1937; Chapra, 2007). We think that development and progress of societies should be measured along these dimensions. A society is progressing if adequate protections are provided to the individuals, and to the society, for their faith, life, intellect, progeny and wealth. Accordingly, a society or an individual is poor if it falls short in these five protections from some minimum acceptable threshold level in some or in all dimensions. A maqāssid al-Sharī'ah based development index was created by us on experimental basis on these lines (see Ali \& Hasan, 2014). We will refer to that index as MSDI. Since we want to analyze the impact of religiosity on multidimensional poverty, we do not include deprivation in the protection of faith in the calculation of maquassid al-Shari 'ah (MS) based multidimensional poverty for this paper. We then analyze how the religiosity can affect the incidence and severity of poverty across religious and non-religious groups. 


\section{Methodology and Data}

To carry out this analysis, the following steps were taken: The first is to define some measure of religiosity. The second is to define multidimensional poverty. The third aspect would be to find whether any relationship does or does not exist between them.

\subsection{Religiosity}

Defining the concept of religiosity in some measurable terms is also part of the analysis. Instead of basing the measurement of religiosity on some single aspect, the paper uses multiple indicators capturing the belief. This is done by using two types of indicators: the indicators that capture the pronouncement of belief, and the indicators that capture action on the direct obligations of those beliefs. These indicators include (i) belief in God, (ii) a person's own testification whether he describes himself/herself as a religious, non-religious or atheist person. These two constitute the pronouncement of belief. The other two indicators are (iii) attendance in religious services and (iv) frequency of prayers. These are measured on a Likert scale and constitute the action on the obligations of the belief part. These indicators are then combined to form a single index of religiosity. Our approach is closer to Islam's emphasis on belief testified by the required practice of it to determine religiosity. Since WVS asks limited number of questions on religiosity, we used a combination of these two dimensions i.e. belief in God and attendance of religious services. Rees (2009, pp. 14-16) also stresses the importance of combining belief and attendance to religious services as a joint measure of religiosity. However, our way of combining them is different in that we utilize a cut-off approach. Our approach is also different to that of Yusof et al. (2018). They collect primary data (from one province of Indonesia) and make use of a combination of five different dimensions to measure the religiosity of a person.

\subsection{Deprivations, Faith-Deprived, and Multidi- mensional Poverty}

Ali and Hasan (2014) have developed axioms for a maqāșid al-Sharī'ah based measure of poverty. They then chose indicator variables from the available World Values Survey data for each of the five dimensions (faith, life, intellect, posterity, and wealth). We use the same procedure in this study except that we keep the faith dimension separate from the measurement of multidimensional poverty. As before, we selected multiple indicators for each dimension. An averaging of deprivations in indicators within each dimension can give the average deprivation in that dimension.

We utilize the Alkire-Foster (AF) dual-cut methodology to identify the poor (Alkire \& Foster, 2011). First, we defined deprivation cut-offs, the minimum required in the provision of adequate protection of faith, life, intellect, posterity and wealth, respectively. These cut-offs were defined at the indicator level (not at dimension level). Then, for each individual, we measured the level of protection enjoyed by him/her in each of the five dimensions by aggregating the indicators within each dimension by weighted averaging method and marked the level of deprivation in each dimension, if any, for every individual. Each dimension was given equal weight. These weights were then divided among the indicator variables in each dimension. The number of indicator variables are not equal in each dimension. Deprivation is then defined as having less than the adequate level of protection - the cut-off mentioned above. The maqassid al-Sharī $a h$ based multidimensional poverty measurement is developed in Ali and Hasan (2014) and used for policy ranking in Ali and Hasan (2018) where the rationale for the choice of indicators and their weights cut-off thresholds are discussed.

A person is then identified as 'multidimensional material-poor' (MD-Poor), if his/her total deprivation in the four dimensions of life, intellect, posterity, and wealth was greater than or equal to $40 \%$ of the maximum possible total deprivations of the four dimensions. All cutoffs are arbitrary in the poverty analysis. It is based on prudential assessment that a very low cutoff will identify a very small percentage of the population as multidimensional poor. Similarly, a very high cutoff will identify a very large portion of the population as poor. Based on the Global Multidimensional Poverty Index methodology of the UNDP, a cutoff of $40 \%$ to $45 \%$ is judged reasonable. Our earlier effort in the creation of the MSDI also showed that a cutoff range of $40 \%$ to $45 \%$ is reasonable. Further, we tested the robustness of results by varying the cutoff and seeing if it changes the ranking 
of countries in MSDI. We found that it is robust: variation in cutoff preserves the ranking despite the change in poverty head-count.

Deprivations in the faith dimension were calculated but not used in identification of the multidimensional material-poor (MD-Poor). It is used in later analysis to identify faith-deprived (or religiouslypoor) persons.

The indicators used to capture these four material dimensions and faith as the fifth dimension along with their cut-off levels are given in Table 1. These indicators and the cut-off levels are based on the responses to the World Values Survey, wave-6 questionnaire. WVS wave- 6 data set covers 52 countries, surveying 74,042 individuals during 2010-2012 (the list of countries appears later in Table 3, first column).

A person is 'religiously-poor' (or faith-deprived) if he falls below the respective thresholds in three out of the four indicators of faith dimension given in Table 1 . These indicators are chosen in such a way that mere statement of belief in God is not sufficient to indicate religiosity, but confirmation of the belief through the act of worship and attendance in religious services is also a required feature in measuring the religiosity of the individual. The definition of material-poor is already given above.

Table (1) Maqāṣid al-Sharī ah Dimensions and their indicators in WVS 2010-2012

\begin{tabular}{|c|c|c|c|c|}
\hline Dimension & $\begin{array}{l}\text { Variable ID } \\
\text { Number }\end{array}$ & Indicator hint (see full question in the survey) & $\begin{array}{c}\text { Range of } \\
\text { Values }\end{array}$ & $\begin{array}{c}\text { Deprivation } \\
\text { Cut-Off } \\
\text { Point }\end{array}$ \\
\hline \multirow{4}{*}{ FAITH } & V145 & attendance in religious services & 1 to 7 & 6 \\
\hline & V146 & frequency in prayer & 1 to 8 & 8 \\
\hline & V147 & religious, non-religious or atheist person & $1,2,3$ & 3 \\
\hline & V148 & belief in God & 1,2 & 2 \\
\hline \multirow{9}{*}{ LIFE } & V55 & freedom of choice in life & 1 to 10 & 6 \\
\hline & V177 & preferred not to go out at night & 1,2 & 2 \\
\hline & V179 & victim of crime last year & 1,5 & 5 \\
\hline & V180 & immediate family victim of crime last year & 1,5 & 5 \\
\hline & V183 & a war involving my country & 1 to 4 & 3 \\
\hline & V184 & a terrorist attack & 1 to 4 & 3 \\
\hline & V185 & a civil war & 1 to 4 & 3 \\
\hline & V188 & gone without enough food to eat & 1 to 4 & 3 \\
\hline & V189 & felt unsafe from crime in your home & 1 to 4 & 3 \\
\hline \multirow{4}{*}{ INTELLECT } & V182 & not being able to give my children a good education & 1 to 4 & 3 \\
\hline & V248 & highest level of education & 1 to 9 & 6 \\
\hline & V172 & alcohol consumption in streets & 1 to 4 & 4 \\
\hline & V175 & drug sale in streets & 1 to 4 & 4 \\
\hline \multirow{6}{*}{ POSTERITY } & V203 & Homosexuality: justifiable & -10 to -1 & -2 \\
\hline & V203A & Prostitution & -10 to -1 & -1 \\
\hline & V204 & Abortion & -10 to -1 & -2 \\
\hline & V205 & Divorce & & \\
\hline & V206 & sex before marriage & -10 to -1 & -1 \\
\hline & V209 & parents beating children & -10 to -1 & -4 \\
\hline \multirow{4}{*}{ WEALTH/PROPERTY } & V59 & satisfaction with financial situation & 1 to 10 & 9 \\
\hline & V171 & occurrence of robberies & 1 to 4 & 4 \\
\hline & V181 & worry about losing job or not finding a job & 1 to 4 & 3 \\
\hline & V239 & which income group you belong to & 1 to 10 & 5 \\
\hline
\end{tabular}


Note that in the present paper all calculations/ measurements are performed at the level of individuals (i.e., our unit of analysis), and we will continue the analysis at the individuals' level. However, to give the picture of MD-Poverty (i.e. multidimensional poverty with four dimensions of maqāșid al-Sharī ah, without accounting for faith) among different countries we provide in Table 2 the Adjusted Headcount Ratio of MD-Poverty ( $\mathrm{M}_{0}$ of MD-Poverty) in each country and mean deprivation in faith (Headcount Ratio of faith deprived).

Table (2) Adjusted Headcount Ratio of MD-Poverty (on four dimensions from maqāșid al-Sharī ah) and mean faith deprivation, by country

\begin{tabular}{|c|c|c|c|c|c|}
\hline Country & $\begin{array}{c}\text { Mo }_{0} \text { MD-Poverty } \\
\text { as per our approach }\end{array}$ & $\begin{array}{l}\text { Mean depriva- } \\
\text { tion in faith } \\
\text { as per our ap- } \\
\text { proach }\end{array}$ & Country & $\begin{array}{l}\text { Mo MD-Poverty } \\
\text { as per our ap- } \\
\text { proach }\end{array}$ & $\begin{array}{l}\text { Mean deprivation } \\
\text { in faith } \\
\text { as per our ap- } \\
\text { proach }\end{array}$ \\
\hline VF2 & MOnf_cntry_40 & mean_mwfaith_nf & VF2 & MOnf_cntry_40 & mean_mwfaith_nf \\
\hline Algeria & 0.197017 & 0.076035 & New Zealand & 0.257372 & 0.13629 \\
\hline Armenia & 0.078709 & 0.091257 & Nigeria & 0.204724 & 0.060569 \\
\hline Australia & 0.282363 & 0.142275 & Pakistan & 0.149725 & 0.071136 \\
\hline Azerbaijan & 0.048643 & 0.116822 & Palestine & 0.07401 & 0.076042 \\
\hline Belarus & 0.231739 & 0.125817 & Peru & 0.308264 & 0.08877 \\
\hline Chile & 0.28243 & 0.105036 & Philippines & 0.304333 & 0.077059 \\
\hline China & 0.144209 & 0.175147 & Poland & 0.187536 & 0.089162 \\
\hline Colombia & 0.252579 & 0.085449 & Qatar & 0.01767 & 0.05 \\
\hline Cyprus & 0.11165 & 0.104545 & Romania & 0.131085 & 0.09504 \\
\hline Ecuador & 0.228128 & 0.092085 & Russia & 0.283784 & 0.119228 \\
\hline Egypt & 0.128142 & 0.05 & Rwanda & 0.358448 & 0.071519 \\
\hline Estonia & 0.241181 & 0.153213 & Singapore & 0.177272 & 0.117411 \\
\hline Germany & 0.187757 & 0.15402 & Slovenia & 0.134032 & 0.125487 \\
\hline Ghana & 0.152236 & 0.065333 & South Korea & 0.135183 & 0.153016 \\
\hline Iraq & 0.125558 & 0.082983 & Spain & 0.22238 & 0.138032 \\
\hline Japan & 0.243254 & 0.142103 & Sweden & 0.199602 & 0.156311 \\
\hline Jordan & 0.063258 & 0.073786 & Taiwan & 0.236284 & 0.125896 \\
\hline Kazakhstan & 0.195787 & 0.117857 & Trinidad & 0.152873 & 0.083471 \\
\hline Kuwait & 0.033331 & 0.05 & Tunisia & 0.099361 & 0.098742 \\
\hline Kyrgyzstan & 0.13804 & 0.088714 & Turkey & 0.069695 & 0.09507 \\
\hline Lebanon & 0.165483 & 0.098387 & Ukraine & 0.265573 & 0.116153 \\
\hline Libya & 0.087194 & 0.069663 & United States & 0.156151 & 0.115135 \\
\hline Malaysia & 0.128992 & 0.090433 & Uruguay & 0.32113 & 0.115008 \\
\hline Mexico & 0.284395 & 0.094938 & Uzbekistan & 0.088387 & 0.107951 \\
\hline Morocco & 0.177017 & 0.064948 & Yemen & 0.0935 & 0.092143 \\
\hline Netherlands & 0.238838 & 0.150824 & Zimbabwe & 0.21368 & 0.07321 \\
\hline
\end{tabular}




\section{Analysis}

\subsection{Slicing by Multidimensional Poverty}

To address our first question, "Is religiosity similar among multidimensional-poor and non-poor?", we separated the results into two groups, i.e., the individuals identified as Multidimensional-Poor (MDPoor) and the individuals identified as Multidimensional-Non-Poor (MD-Non-Poor). Then, for each individual we calculated faith deprivation. An individual is faith-deprived if his score is below the thresholds in at least 2 out of the 4 indicators of faith. The four indicators of faith and their respective thresholds are given in Table 1. Each indicator is censored to 1 if the individual falls below the indicator specific threshold level, and 0 otherwise. The censored indicators are then multiplied by the weight of each indicator (in this case, the 4 indicators were equally weighted). The weighted sum of all four censored indicators of faith shows the intensity of deprivation of each individual in the faith dimension. Then, for each poor and non-poor group we calculated the mean level of faith deprivation. We then compare these means to check if they are equal or they are different (i.e., the mean of the intensity over all the individuals in the MD-Poor group is compared with that for the MD-Non-Poor group). This provides us a way to assess the difference in religiosity associated with poverty. We also performed the test of statistical significance of this difference.

We found that the mean of faith deprivation of MD-Poor group is 0.095348 which is greater than the mean of faith deprivation of MD-Non-Poor group that is 0.081321 . The difference has 99 percent statistical significance; therefore, we conclude that the multidimensional poor (MD-Poor) are less religious than the MD-Non-Poor group (see Appendix Table A2 for the statistical test details).

The overall test with data pooled over all 52 countries would obscure the differences that may exist across countries. Therefore, we did the same analysis country by country. Dividing the population in MDPoor and MD-Non-Poor for each country and testing the difference of means. The detailed results are reported in Table 3.

As it turned out, 25 countries show results with high statistical significance (99\% and 95\% significance level) that, on average, faith deprivation is higher among MD-Poor groups of people than among MD-Non-Poor groups of people in these countries. That is, poor are less religious than nonpoor. Only in three countries it is the opposite, i.e., in three countries the more religious people are MDPoor. It is interesting to note that these three countries are Azerbaijan, China, and Uzbekistan. Here the deprivation may be government enforced, not the outcome of personal, societal, or economic factors (it should be noted that if a person or group is more intensely deprived in faith, it is less religious). In the rest of the 24 countries, either the differences of means are not statistically significant or the differences in means are negligible in magnitude. These results, taken together, give the picture that higher religiosity is not associated with higher MD-Poverty; rather, higher religiosity is associated with lower MD-Poverty. One is tempted to say that the conclusion points to the possibility that religion reduces poverty. However, the present paper is not geared towards the testing of causality of this relationship.

Our results contrast with earlier studies in that those studies did not look at the relation between poverty and religion but analyzed the relation between religiosity and insecurity in the context of explaining religiosity as a consequence of 'societal insecurity'. According to those studies, religiosity and 'societal insecurity' are positively correlated. However, our results showing the relationship between poverty and religiosity are congruent with the Islamic teachings that poverty is undesirable because poverty can lead to disbelief. In the Islamic context, extreme poverty is bad because not only it is a social evil that affects wellbeing in this world, it is also dangerous for life in the hereafter because it can lead to shaking the true belief in Allah. 
Table (3) Association of Faith Deprivation with MD-Poverty

\begin{tabular}{|c|c|c|c|c|c|c|}
\hline \multicolumn{7}{|c|}{ Test of equality of means of faith deprivation in the MD-Poor and MD-Non-Poor groups in each country } \\
\hline Country & $\begin{array}{l}\text { Difference } \\
\text { in Mean }\end{array}$ & t-value & p-value & Significance & $\begin{array}{l}\text { Color } \\
\text { Code }\end{array}$ & Conclusion \\
\hline Algeria & 0.006044 & 2.386429 & 0.017167 & ** & & $\begin{array}{l}\text { faith deprivation of poor group is higher than } \\
\text { faith deprivation of non-poor group }\end{array}$ \\
\hline Armenia & -0.00274 & -0.93949 & 0.347687 & & & Very small negative difference \\
\hline Australia & 0.015431 & 4.66639 & $3.34 \mathrm{E}-06$ & $* * *$ & & $\begin{array}{l}\text { faith deprivation of poor group is higher than } \\
\text { faith deprivation of non-poor group }\end{array}$ \\
\hline Azerbaijan & -0.01343 & -3.27972 & 0.001075 & $* * *$ & & $\begin{array}{l}\text { faith deprivation of poor group is lower than } \\
\text { faith deprivation of non-poor group }\end{array}$ \\
\hline Belarus & 0.008385 & 3.547367 & 0.000401 & $* * *$ & & $\begin{array}{l}\text { faith deprivation of poor group is higher than } \\
\text { faith deprivation of non-poor group }\end{array}$ \\
\hline Chile & 0.006422 & 2.254844 & 0.024359 & $* *$ & & $\begin{array}{l}\text { faith deprivation of poor group is higher than } \\
\text { faith deprivation of non-poor group }\end{array}$ \\
\hline China & -0.00867 & -3.80113 & 0.000148 & $* * *$ & & $\begin{array}{l}\text { faith deprivation of poor group is lower than } \\
\text { faith deprivation of non-poor group }\end{array}$ \\
\hline Colombia & 0.005555 & 2.269518 & 0.023377 & $* *$ & & $\begin{array}{l}\text { faith deprivation of poor group is higher than } \\
\text { faith deprivation of non-poor group }\end{array}$ \\
\hline Cyprus & -0.00069 & -0.21766 & 0.827735 & & & No difference between the two groups \\
\hline Ecuador & 0.003733 & 1.386789 & 0.165764 & & & Very small positive difference \\
\hline Egypt & 0.001426 & 1.042477 & 0.297356 & & & Very small positive difference \\
\hline Estonia & 0.007455 & 2.779136 & 0.005517 & $* * *$ & & $\begin{array}{l}\text { faith deprivation of poor group is higher than } \\
\text { faith deprivation of non-poor group }\end{array}$ \\
\hline Germany & 0.011133 & 4.629795 & $3.89 \mathrm{E}-06$ & $* * *$ & & $\begin{array}{l}\text { faith deprivation of poor group is higher than } \\
\text { faith deprivation of non-poor group }\end{array}$ \\
\hline Ghana & 0.003542 & 1.786532 & 0.074209 & $*$ & & Very small positive difference \\
\hline Iraq & 0.012426 & 3.950764 & $8.25 \mathrm{E}-05$ & $* * *$ & & $\begin{array}{l}\text { faith deprivation of poor group is higher than } \\
\text { faith deprivation of non-poor group }\end{array}$ \\
\hline Japan & 0.000717 & 0.395825 & 0.692269 & & & No difference between the two groups \\
\hline Jordan & 0.006319 & 1.643593 & 0.100523 & & & $\begin{array}{l}\text { faith deprivation of poor group is higher than } \\
\text { faith deprivation of non-poor group }\end{array}$ \\
\hline Kazakhstan & 0.00065 & 0.29527 & 0.767828 & & & No difference between the two groups \\
\hline Kuwait & 0.002404 & 1.032745 & 0.301915 & & & Very small positive difference \\
\hline Kyrgyzstan & 0.005875 & 2.314566 & 0.020771 & $* *$ & & $\begin{array}{l}\text { faith deprivation of poor group is higher than } \\
\text { faith deprivation of non-poor group }\end{array}$ \\
\hline Lebanon & 0.001946 & 0.59923 & 0.549133 & & & Very small positive difference \\
\hline Libya & 0.005393 & 2.391344 & 0.016873 & $* *$ & & $\begin{array}{l}\text { faith deprivation of poor group is higher than } \\
\text { faith deprivation of non-poor group }\end{array}$ \\
\hline Malaysia & 0.006977 & 2.110335 & 0.03502 & $* *$ & & $\begin{array}{l}\text { faith deprivation of poor group is higher than } \\
\text { faith deprivation of non-poor group }\end{array}$ \\
\hline Mexico & 0.00631 & 2.774382 & 0.005582 & $* * *$ & & $\begin{array}{l}\text { faith deprivation of poor group is higher than } \\
\text { faith deprivation of non-poor group }\end{array}$ \\
\hline Morocco & -0.003 & -1.72494 & 0.084797 & $*$ & & Very small negative difference \\
\hline Netherlands & 0.004853 & 1.600168 & 0.109728 & & & $\begin{array}{l}\text { faith deprivation of poor group is higher than } \\
\text { faith deprivation of non-poor group }\end{array}$ \\
\hline $\begin{array}{l}\text { New Zea- } \\
\text { land }\end{array}$ & 0.019705 & 4.642504 & $3.99 \mathrm{E}-06$ & $* * *$ & & $\begin{array}{l}\text { faith deprivation of poor group is higher than } \\
\text { faith deprivation of non-poor group }\end{array}$ \\
\hline Nigeria & -0.00222 & -1.41916 & 0.156029 & & & Very small negative difference \\
\hline Pakistan & 0.006744 & 3.09003 & 0.002047 & $* * *$ & & $\begin{array}{l}\text { faith deprivation of poor group is higher than } \\
\text { faith deprivation of non-poor group }\end{array}$ \\
\hline Palestine & $3.11 \mathrm{E}-05$ & 0.007774 & 0.993799 & & & No difference between the two groups \\
\hline Peru & 0.004107 & 1.586166 & 0.112963 & & & Very small positive difference \\
\hline
\end{tabular}




\begin{tabular}{|c|c|c|c|c|c|c|}
\hline \multicolumn{7}{|c|}{ Test of equality of means of faith deprivation in the MD-Poor and MD-Non-Poor groups in each country } \\
\hline Country & $\begin{array}{l}\text { Difference } \\
\text { in Mean }\end{array}$ & t-value & p-value & Significance & $\begin{array}{l}\text { Color } \\
\text { Code }\end{array}$ & Conclusion \\
\hline Philippine & 0.004188 & 1.513284 & 0.130471 & & & Very small positive difference \\
\hline Poland & 0.010787 & 3.469405 & 0.000545 & $* * *$ & & $\begin{array}{l}\text { faith deprivation of poor group is higher than } \\
\text { faith deprivation of non-poor group }\end{array}$ \\
\hline Qatar & 0.004174 & 1.563976 & 0.118122 & & & Very small positive difference \\
\hline Romania & 0.0081 & 2.964503 & 0.00308 & $* * *$ & & $\begin{array}{l}\text { faith deprivation of poor group is higher than } \\
\text { faith deprivation of non-poor group }\end{array}$ \\
\hline Russia & 0.002278 & 1.157214 & 0.247296 & & & Very small positive difference \\
\hline Rwanda & -0.00353 & -1.45976 & 0.144563 & & & Very small negative difference \\
\hline Singapore & 0.009658 & 3.422278 & 0.000634 & $* * *$ & & $\begin{array}{l}\text { faith deprivation of poor group is higher than } \\
\text { faith deprivation of non-poor group }\end{array}$ \\
\hline Slovenia & 0.004371 & 1.201498 & 0.229825 & & & Very small positive difference \\
\hline South Korea & 0.009767 & 2.11262 & 0.03484 & $* *$ & & $\begin{array}{l}\text { faith deprivation of poor group is higher than } \\
\text { faith deprivation of non-poor group }\end{array}$ \\
\hline Spain & 0.011739 & 4.126031 & $3.95 \mathrm{E}-05$ & $* * *$ & & $\begin{array}{l}\text { faith deprivation of poor group is higher than } \\
\text { faith deprivation of non-poor group }\end{array}$ \\
\hline Sweden & 0.002923 & 1.006845 & 0.314212 & & & Very small positive difference \\
\hline Taiwan & 0.00908 & 3.476276 & 0.000526 & $* * *$ & & $\begin{array}{l}\text { faith deprivation of poor group is higher than } \\
\text { faith deprivation of non-poor group }\end{array}$ \\
\hline Trinidad & 0.000404 & 0.123919 & 0.901404 & & & No difference between the two groups \\
\hline Tunisia & $-3.4 \mathrm{E}-05$ & -0.00851 & 0.993213 & & & No difference between the two groups \\
\hline Turkey & 0.014318 & 4.225686 & $2.52 \mathrm{E}-05$ & $* * *$ & & $\begin{array}{l}\text { faith deprivation of poor group is higher than } \\
\text { faith deprivation of non-poor group }\end{array}$ \\
\hline Ukraine & 0.009749 & 3.820489 & 0.000139 & $* * *$ & & $\begin{array}{l}\text { faith deprivation of poor group is higher than } \\
\text { faith deprivation of non-poor group }\end{array}$ \\
\hline $\begin{array}{l}\text { United } \\
\text { States }\end{array}$ & 0.020216 & 7.572549 & $5.33 \mathrm{E}-14$ & $* * *$ & & $\begin{array}{l}\text { faith deprivation of poor group is higher than } \\
\text { faith deprivation of non-poor group }\end{array}$ \\
\hline Uruguay & 0.008396 & 2.441601 & 0.014795 & $* *$ & & $\begin{array}{l}\text { faith deprivation of poor group is higher than } \\
\text { faith deprivation of non-poor group }\end{array}$ \\
\hline Uzbekistan & -0.01118 & -5.06482 & 4.60E-07 & $* * *$ & & $\begin{array}{l}\text { faith deprivation of poor group is lower than } \\
\text { faith deprivation of non-poor group }\end{array}$ \\
\hline Yemen & 0.004087 & 1.106318 & 0.268855 & & & Very small positive difference \\
\hline Zimbabwe & 0.007199 & 3.194533 & 0.00143 & $* * *$ & & $\begin{array}{l}\text { faith deprivation of poor group is higher than } \\
\text { faith deprivation of non-poor group }\end{array}$ \\
\hline
\end{tabular}

\subsection{Slicing by Faith Poverty}

To take up the second question, "Is there any difference in dimensions of deprivations among high religiosity and low religiosity people?", we move to analyze the data by slicing it in another way. This time we slice it into two groups: Faith-Poor and Not-FaithPoor, by defining a $40 \%$ cutoff for the faith dimension. That is, any person who is deprived in faith equal to or more than $40 \%$ of the maximum possible deprivations is classified as Faith-Poor. We then analyze how the Faith-Poor compare with Not-FaithPoor in their other four dimensions of poverty. The results for global average deprivations in each of the dimensions are reported in the following tables $4 \mathrm{a}$ and $4 \mathrm{~b}$.

As can be seen, on the global average, the faithpoor are more deprived in intellect and posterity and less deprived in life and property, compared to nonfaith-poor. This shows that faith affects (or faith is associated with) multidimensional poverty through different dimensions and in different ways. Two tailed t-tests for difference in means across the two groups (Table 4c), for each dimension, reject the null hypothesis of equality of means and accept the alternative hypothesis of unequal means. 
It may be the case that, the faith-poor are less conscious of posterity protection because of their liberal views and responsibility-free attitude about sex, marriage, divorce, and rearing of children. They are also falling short in the protection of mind/intellect by living in neighborhoods that are prone with alcoholic consumption and sale of drugs on streets. While the present paper does not analyze neighborhood as a reason explicitly, we are able to make this preliminary judgment because the questions in the WVS about alcohol consumption and drug use were asked relating them to the neighborhood of the respondent. For example, the question: "How frequently do the following things occur in your neighborhood? (a) Alcohol consumption in the streets. (b) Drug sale in streets". This provides a clue to possible reasons. The faith-poor may be concerned about these, but they have not corrected the situation in their neighborhoods or, failing it, not moved to better places. This is either because they are unable to correct or that they are unable to move. It can also be that they can afford to move but see the cost of continuation of living in their present neighborhoods less than the cost of moving. Correlation analysis between these four dimensions also shows that intellect deprivation and posterity deprivation are positively correlated among the faith poor group.

Table (4a) Summary Statistics for Faith-Poor (global data, that is all countries)

\begin{tabular}{|c|c|c|c|c|}
\hline \multicolumn{5}{|c|}{ Summary Statistics of the four dimensions of deprivations when person is classified as Faith-Poor } \\
\hline Deprived in & Life & Intellect & Posterity & Wealth \\
\hline Variable Name & fpwlife_nf & fpwintelle $\sim f$ & fpwposteri f & fpwpropert $\sim f$ \\
\hline Observation & 41183 & 41183 & 41183 & 41183 \\
\hline Mean & 0.068703 & 0.101059 & 0.093598 & 0.116341 \\
\hline Std. Dev. & 0.042858 & 0.051947 & 0.061191 & 0.050176 \\
\hline Min. & 0 & 0 & 0 & 0 \\
\hline \multirow[t]{2}{*}{ Max. } & 0.2 & 0.2 & 0.2 & 0.2 \\
\hline & & $>$ & $>$ & \\
\hline
\end{tabular}

Table (4b) Summary Statistics for NOT Faith-Poor (global data, that is all countries)

\begin{tabular}{ccccc}
\hline \multicolumn{5}{c}{ Summary Statistics of the four dimensions of deprivations when person is classified as NOT Faith-Poor } \\
\hline Deprived in & Life & Intellect & Posterity & Wealth \\
Variable Name & nfpwlife_nf & nfpwintell $\sim f$ & nfpwposter $\sim f$ & nfpwproper $\sim f$ \\
\hline Observation & 32859 & 32859 & 32859 & 32859 \\
Mean & 0.081225 & 0.094018 & 0.055388 & 0.120128 \\
Std. Dev. & 0.040603 & 0.053683 & 0.058028 & 0.050466 \\
Min. & 0 & 0 & 0 & 0 \\
Max. & 0.2 & 0.2 & 0.2 & 0.2 \\
& $>$ & & & $>$ \\
\hline
\end{tabular}

Table (4c) Test of Difference in Means. Ho: Equal Means

\begin{tabular}{ccccc}
\hline Deprived in & Life & Intellect & Posterity & Wealth \\
\hline Mean1-Mean2 & -0.01252 & 0.007041 & 0.03821 & -0.00379 \\
SE Standard Error & 0.000308 & 0.000391 & 0.00044 & 0.000372 \\
t-statistic & -40.6753 & 17.98725 & 86.88688 & -10.1707 \\
\hline
\end{tabular}


Knowing that the pattern of deprivations among faith-poor and Not-faith-poor may vary across different countries. We can also do country-wise analysis of difference of means among the two groups in each country. This is deferred for future research in order to be able to focus on one issue at a time. However, in order to show a general picture of how the four dimensions vary across the countries in their relationship to faith deprivation, we plot four graphs with each dot representing a country (see Figure 1). It is found that, overall, both posterity deprivation and intellect deprivation increase with the increase in faith deprivation. While both life deprivation and property deprivation fall with the increase in faith deprivation.

Figure (1) Plot of Faith Deprivation vs deprivation in other four dimensions-Cross Country data

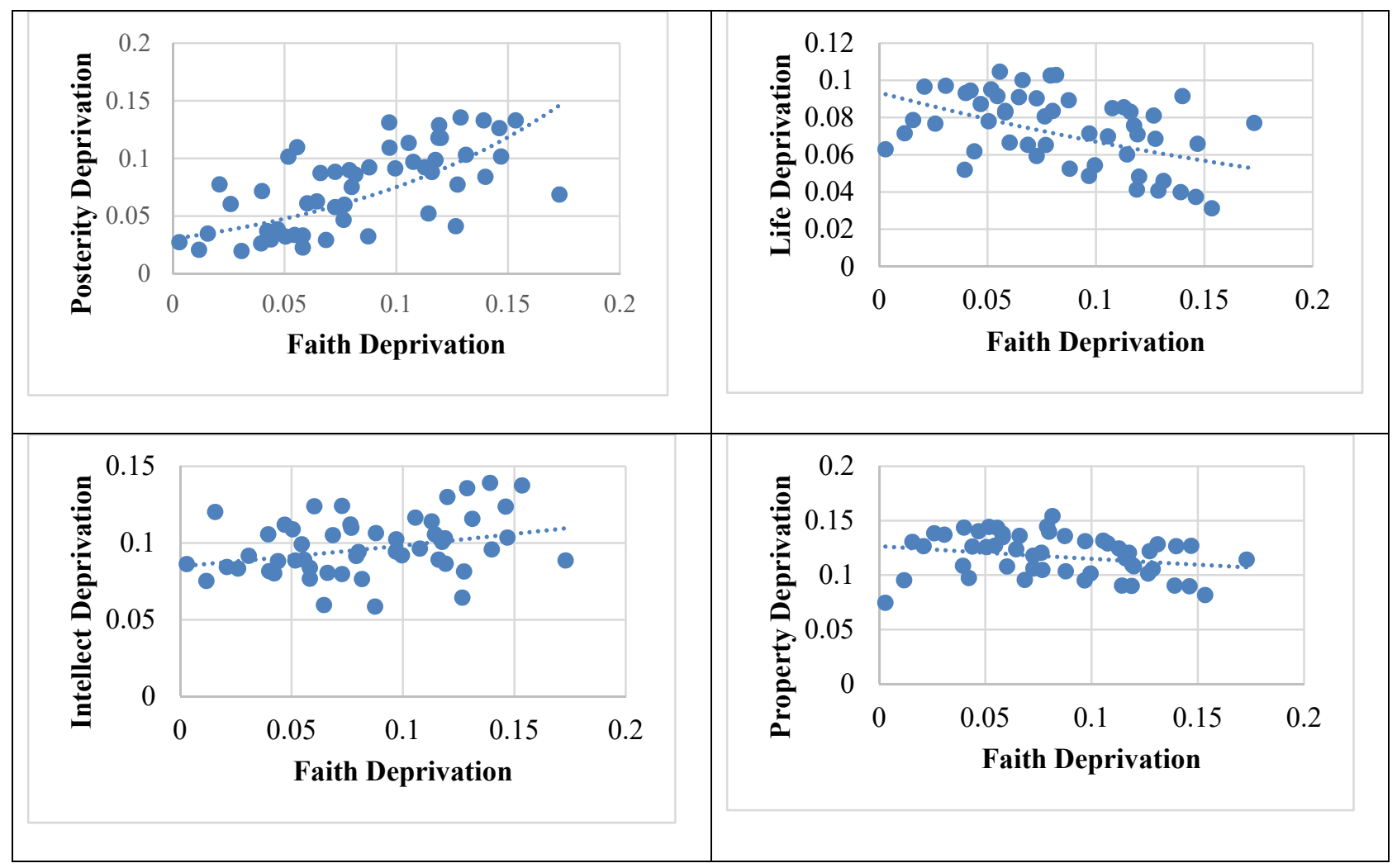

\subsection{Cross-Country Analysis}

Note that until now we have worked with simple correlations only, as questions Q1 and Q2 require just that. We now take up the third question, "What is the impact of religiosity on multi-dimensional poverty?".

To account for other determinants of multidimensional poverty along with religiosity, we perform cross-country regression analysis. Regressions involve partial correlations conditional on other variables remaining fixed.

Our basic regression model-1 is:

MSI Poverty $=\mathrm{c}+\mathrm{b}($ mean Faith Deprivation $)+\mu$ where, the data is by country and the regression is estimated for the full sample of 52 countries.

It can be augmented to include some control variables to control for the country specific affects. In particular, GDP per capita (defined as log of mean value of GDP per capita during 2010 to 2012, that is the period of WVS wave-6 survey) was used to control for country specific affects that can influence MSI Poverty. However, the number of countries were reduced due to missing data on control variables for some countries.

The use of GDP per capita averaged over the survey period seems a useful control to capture a variety 
of country specific factors. In many studies, GDP per capita has been identified as an important determinant of income poverty. GDP per capita is also influenced by governance and other country specific factors. Therefore, variation across countries in the GDP per capita averaged over a three-year period could well capture the variations in key exogenous country specific factors. Our approach is also consistent with Bettendorf and Dijkgraaf (2010) who found heterogeneity across countries in relating religion to income: more developed (high income) countries exhibiting positive relationship and less developed (low income) countries exhibiting negative relationship. Thus, our control variable GDP per capita seems useful to capture and isolate that effect.

The general form of the augmented model is as follows:

MSI Poverty $=\mathrm{c}+\mathrm{b}$ (mean Faith Deprivation) $+\mathrm{d}$ (Country Specific Variable) $+\varepsilon$

However, in regressions, the coefficients are conditional covariances and the conditionality has some hint of causality in theory, if not in its empirics. The issue of endogeneity between multidimensional poverty and faith deprivation could be relevant here in equations 1 and 2 . That is, if average faith deprivation in a country (the right-hand side variable) is affected by multidimensional poverty in that country (the lefthand side variable), then there is a feed-back effect and hence an endogeneity that needs to be corrected. The source of this endogeneity is that the errors in multidimensional poverty (the term $\varepsilon$ ) now contains errors of the explanatory variable, i.e., average faith deprivation in equation 2 . Therefore equations 1 and 2 are not reported as such but after modification to account for endogeneity issue.

To correct for the endogeneity problem, several approaches are possible. One approach is to continue working with a single equation such as equation 2 above but use an appropriate instrumental variable for mean Faith Deprivation which is not correlated with the error term. We created two innovative instrumental variables that we used one after the other in the analysis as explained in subsections 5.3.1 and 5.3.2 below. Another approach is to create a simultaneous equation model with one equation having MSI Poverty as the dependent variable and the other equation having mean Faith Deprivation as the dependent variable and use 2SLS method with appropriate instruments. This is also done and analyzed in subsection 5.3.3 below.

\subsubsection{Using faith of non-poor as proxy}

To correct for endogeneity problem, we regress multidimensional MSI Poverty on mean faith deprivation of non-poor (equation 3a) and its augmented form with GDP per capita (equation 3b)

MSI Poverty $=\mathrm{c} 1+\mathrm{b} 1$ (mean Faith Deprivation of non-poor) $+\varepsilon$

MSI Poverty $=\mathrm{c} 1+\mathrm{b} 1$ (mean Faith Deprivation of non-poor $)+\mathrm{d} 1$ (Country Specific Variable) $+\varepsilon$ (3b)

We further checked if it makes any difference by running the regression of multidimensional MSI Poverty on mean faith deprivation of the poor (equation 4a) and its augmented form with GDP per capita included (equation $4 \mathrm{~b}$ )

MSI Poverty $=\mathrm{c} 2+\mathrm{b} 2$ (mean Faith Deprivation of poor $)+\varepsilon$

MSI Poverty $=\mathrm{c} 2+\mathrm{b} 2$ (mean Faith Deprivation of poor $)+\mathrm{d} 2$ (Country Specific Variable) $+\varepsilon$

Note that in equations $3 \mathrm{a}$ and $3 \mathrm{~b}$, the left-hand side variable (either a headcount $\mathrm{H}$ or a severity adjusted headcount $\mathrm{M}_{0}$ ) pertains to the poor people. While the right-hand side of the same equation incorporates faith deprivation of non-poor. Therefore, the error terms across the two groups, poor and non-poor, may not be correlated in equations $3 a$ and $3 b$.

However, spurious correlation can be found in equations $4 \mathrm{a}$ and $4 \mathrm{~b}$ because MSI poverty (on left) and mean Faith Deprivation of Poor (on right) pertain to poor only and, hence, the errors in these two variables may be correlated.

The regressions (equations $3 \mathrm{a}, 3 \mathrm{~b}$, and even $4 \mathrm{a}$, and $4 \mathrm{~b}$ ) show that religiosity (as measured by low deprivation in faith) does matter in its impact on multidimensional poverty. An increase in deprivation of faith (i.e. a decrease in religiosity) increases multidimensional poverty. Though we have not searched for the route through which religiosity can influence multidimensional poverty, however, some thoughts can be offered. Religiosity increases satisfaction with one's financial situation and decreases concerns about relative income compared to others. It also 
increases concern for the wellbeing of children and changes attitudes towards sex, marriage, and divorce. Because religions always have something to say about these issues, they directly influence these aspects of human life. Faith and religiosity also contribute in defining the values and morals of the society. Hence, it has an influence on crime rate, life protection, and knowledge seeking behavior. It is true that religious conflict can sometimes bring about violence which increases threat to life and property, but that too comes with the objective of providing protection in the perception of believers in one or the other religion.

Table (5) Regression of MSI Poverty on faith deprivation and other variables

\begin{tabular}{|c|c|c|c|c|c|c|c|c|}
\hline \multirow{5}{*}{$\begin{array}{l}\text { Variables } \\
\text { Mean Faith } \\
\text { deprivation } \\
\text { among poor }\end{array}$} & \multirow[b]{4}{*}{ Variable Name } & 1 & 2 & 3 & 4 & \multirow{2}{*}{$\frac{5}{(\text { eq4a) }}$} & 6 & \multirow{3}{*}{$\begin{array}{c}7 \\
\text { (eq5 \& } \\
\text { eq6) } \\
\text { 2SLS } \\
\text { model }\end{array}$} \\
\hline & & (eq4a) & (eq4b) & (eq3a) & (eq3b) & & (eq4b) & \\
\hline & & ------------ & ------ Witl & ll sample -- & ---------- & \multicolumn{2}{|c|}{$\begin{array}{l}\text { With restricted sample of } \\
\text { stable age population }\end{array}$} & \\
\hline & & & & & & & & \\
\hline & mean_mwfaith_nf & $0.779 * *$ & $1.043 * *$ & & & $0.724 * *$ & $0.987 * *$ & $0.427 * * *$ \\
\hline & & $(0.335)$ & $(0.414)$ & & & $(0.329)$ & $(0.415)$ & $(0.0628)$ \\
\hline \multirow{2}{*}{$\begin{array}{l}\text { Mean Faith } \\
\text { deprivation } \\
\text { among non- } \\
\text { poor }\end{array}$} & mean_mwfaith_nfo & & & $0.712 * *$ & $0.897 * *$ & & & \\
\hline & & & & $(0.344)$ & $(0.446)$ & & & \\
\hline \multirow{6}{*}{$\begin{array}{l}\text { GDP Per- } \\
\text { capita }\end{array}$} & $g d p \_p c$ & & -0.0134 & & -0.107 & & -0.0138 & - \\
\hline & & & $(0.0106)$ & & $(0.011)$ & & $(0.0111)$ & $(0.0005)$ \\
\hline & Constant & $0.0991 * *$ & $0.191 * *$ & $0.108 * * *$ & $0.184 * * *$ & $0.106 * * *$ & $0.202 * *$ & $0.215 * * *$ \\
\hline & & $(0.0385)$ & $(0.0812)$ & $(0.0375)$ & $(0.0814)$ & $(0.0386)$ & $(0.0844)$ & $(0.0029)$ \\
\hline & Observations & 52 & 51 & 52 & 51 & 52 & 51 & 72804 \\
\hline & $R$-squared & 0.088 & 0.119 & 0.073 & 0.093 & 0.079 & 0.109 & 0.084 \\
\hline
\end{tabular}

Notes: Robust standard errors in parentheses.

$* * * \mathrm{p}<0.01, * * \mathrm{p}<0.05, * \mathrm{p}<0.1$

\subsubsection{Using faith of stable-age group as proxy}

Another way to control for endogeneity is to restrict the sample to the age group of 24 to 56 years old individuals in each country for the entire analysis. The logic for this is the fact that religiosity does not change quickly. The changes take place relatively fast in the early developmental phase of life and it is set by the early 20 years of life.

In a recent paper, Ruck et al. (2018) tracked religiosity and economic development over a century. They utilized a similar kind of logic stating that religiosity is developed in the first or second decade of life and then it is carried over. Using the data of religiosity and age of people from resent surveys, they used birth cohort approach to attribute the religiosity of each cohort to the decade in which the respondents were around 20 years old. Thus, they created a retrospective time series of religiosity that is independent of present-day level of economic development.

Religiosity also changes in the late phase of life due to long experience and more time after retirement for contemplation to search for purpose in life (Hayward \& Krause, 2015). During the age of 24 to 56 years, religiosity is expected to be more stable and not quickly affected by changes in the poverty status of the person. Thus, poverty can be explained by religiosity as a factor, but religiosity will not be considerably affected by poverty during that period of life. That is, chances of reverse causality from poverty to religiosity are small during this period.

Restricting the sample in this way reduces the individual respondents in the dataset from 74,042 to 46,941 with a minimum of 463 respondents and a 
maximum of 1,574 respondents from any country (see Appendix Table A3 for country-wise details). This is still a large number per country to satisfactorily calculate poverty and faith deprivation values for each country.

Table 5, columns 5 and 6 show the results of reestimation of the same model as that in columns 1 and 2 but with the sample restricted to the age group of 24 to 56 years old in each country. The coefficient of mean faith deprivation of the poor is 0.987 , which is positive and statistically significant. The result confirms that the poverty of the poor is increased by increase in irreligiosity (the deprivation of faith).

\subsubsection{Using two-stage least square estimation}

As an additional way to control for endogeneity, we also applied instrument variable approach using 2SLS method. It is hard to find suitable instruments for faith deprivation from within the data set we use. Moreover, so far, our approach was to measure faith deprivation as directly as possible to capture this difficult variable. Creating an instrument for faith deprivation would now add a further layer of indirectness which we wanted to avoid. Nevertheless, we used V55, V242 and V170 from WVS-6 (i.e. lack of control in life, age, and insecurity, respectively) as instruments for faith deprivation among non-poor. The theory behind selecting these variables is that people become more inclined towards religion when they: feel lack of control over many things in life; when they age and hence gain more experience or may now have more free time available with age to think; and when they feel more insecure. This choice of instruments is aligned with the earlier literature. For example, Rees (2009, p. 12) shows that personal insecurity can increase the intensity of religious belief. According to him, religiosity is a consequence of personal insecurity. He uses income inequality as proxy for personal insecurity. Earlier, Norris and Ingelhart (2004) also promoted the same idea. We used 'lack of control in life' and 'insecurity' directly from the survey data instead of using income inequality. Had we used income inequality, it would have become a proxy for the proxy for our desired variable.

Specifically, the following simultaneous equation model represented by equations 5 and 6 was estimat$\mathrm{ed}^{(2)}$, and the results are summarized in column 7 of

(2) In terms of STATA specification: ivregress 2sls M0nf_cntry_40 gdp_pc (wfaith_nf = V55 V242 insecurity).
Table 5.

MSI Poverty $=\mathrm{c} 3+\mathrm{b} 3$ (Faith Deprivation of poor) $+\mathrm{d} 3$

(GDP per Capita) $+\varepsilon$

Faith Deprivation of poor $=\mathrm{g}+\mathrm{h} 1(\mathrm{~V} 55)+\mathrm{h} 2(\mathrm{~V} 242)+$ $\mathrm{h} 3$ (insecurity) $+\mu$

The estimation results also show that the faith deprivation impacts MSI-poverty. An increase in faith deprivation increases poverty. The high Wald Chi square statistic $=112.31$ indicates validity of instruments.

In short, multidimensional poverty defined in a more comprehensive sense, as in this paper, is influenced by religion and religiosity of the people. A religious society is less poor multidimensionally than a society with lesser religiosity. Future research can formulate ways to capture the main content of a religion itself and determine how its teachings and beliefs help reducing poverty.

\section{Conclusion}

There is a realization now that poverty is a multidimensional phenomenon. The present paper created a multidimensional poverty measure synthesizing deprivations in four key dimensions of human life. That is, deprivations from a minimum threshold in the protection of (i) life, (ii) intellect, (iii) progeny, and (iv) property/wealth. This measure was applied to 52 countries based on the data from World Values Survey wave-6 covering the period 2010-2012. It also created a measure of religiosity taking into consideration both the faith/beliefs and practice of those beliefs in life. It then attempted to see the association between religiosity and multidimensional poverty defined in the above sense.

In summary, the results indicate that the general perception that religion contributes to poverty or that poor people tend to be more religious is not true when poverty is measured in a more comprehensive multidimensional form. Similarly, the perception that the countries where religious values are given more importance are constraining themselves ending up with more poverty than others is also not true. Specifically, higher religiosity is not associated with higher multidimensional-poverty; rather, higher religiosity is associated with lower multidimensionalpoverty. Out of 52 countries analyzed, 25 countries showed with high statistical significance $(99 \%$ and 
95\% significance level) that, on average, faith deprivation is higher among multidimensional-poor groups of people than among multidimensional-nonpoor groups of people. In 3 countries, the results are opposite, and in 24 , the difference in faith deprivation of the two groups is either very small or statistically insignificant.

On average, with all countries taken together, the faith-poor are more deprived in intellect and posterity and less deprived in life and property dimensions, compared to non-faith-poor. This shows that faith

\section{References}

Ali, Salman Syed., \& Hasan, Hamid. (2014, May). Theory and An Application of Maqasid Al-Shariah based Measurement Index for Socio-Economic Development: Index Method and Prototype Index. Paper presented at the Seminar on Developing a Framework for Maqasid al-Shariah based Index of Socio-Economic Development, Jeddah, Saudi Arabia.

Ali, Salman Syed., \& Hasan, Hamid. (2018). Measuring Deprivation from Maqasid al-Shariah Dimensions in OIC Countries: Ranking and Policy Focus. Journal of King Abdulaziz University: Islamic Economics, 31(1), 3-24.

Alkire, S., \& Foster, J.E. (2011). Counting and Multidimensional Poverty Measurement. Journal of Public Economics, 95(7-8), 476-487.

Barro, R.J., \& McCleary, R.M. (2003). Religion and Economic Growth across Countries. American Sociological Review, 68(5), 760-781.

Bettendorf, L., \& Dijkgraaf, E. (2010). Religion and income: Heterogeneity between countries. Journal of Economic Behavior \& Organization, 74(1-2), 12-29.

Beyers, J. (2014). The effect of religion on poverty. HTS Teologiese Studies/ Theological Studies, 70(1). Retrieved from:

https:/hts.org.za/index.php/hts/article/download/2614/ 4708

Chapra, M. U. (2007). The Islamic Vision of Development in the Light of Maqasid Al-Shari'ah. Jeddah, KSA: Islamic Research and Training Institute, Islamic Development Bank.

Crabtree, S. (2010, August 31). Religiosity Highest in World's Poorest Nations: United States is among the rich countries that buck the trend. Gallup News. Retrieved from: http://news.gallup.com/poll/142727/religiosity-highestworld-poorest-nations.aspx affects (or relates) to multidimensional poverty through different dimensions and in different ways.

The regressions with cross section data over countries show that religiosity (as measured by low deprivation in faith) does matter in its impact on multidimensional poverty. An increase in deprivation of faith increases multidimensional poverty.

A policy implication of these findings is that a religious society would be less poor and more inclusive even if its economic growth is slow.

al-Ghazali, A. (1937). al-Mustasfa. Cairo: al-Maktabah alTijariyyah al-Kubra.

Guiso, L., Sapienza, P., \& Zingales, L. (2002). People's Opium? Religion and Economic Attitudes (NBER Working Paper No. 9237). Retrieved from: https://www.nber.org/papers/w9237.pdf

Hayward, R.D., \& Krause, N. (2015). Aging, social developmental, and cultural factors in changing patterns of religious involvement over a 32-year period: An age-period-cohort analysis of 80 countries. Journal of Cross-Cultural Psychology, 46(8), 979-995.

Heath, A., \& Li, Y. (2015). Review of the relationship between religion and poverty: an analysis for the Joseph Rowntree Foundation (Centre for Social Investigation Working Paper No. 2015-01). Retrieved from: http://csi.nuff.ox.ac.uk/wpcontent/uploads/2015/03/religion-and-povertyworking-paper.pdf

Herzer, D., \& Strulik, H. (2017). Religiosity and income: a panel cointegration and causality analysis. Applied Economics, 49(30), 2922-2938.

Iannaccone, L.R. (1998). Introduction to the Economics of Religion. Journal of Economic Literature, 36(3), 1465-1495.

Iyer, S. (2016). The New Economics of Religion. Journal of Economic Literature, 54(2), 395-441.

Jackson, P., \& Fleischer, C. (2007). Religion and Economics: A Literature Review (Religions and Development Research Program Working Paper No. 3, University of Birmingham). Retrieved from: http://epapers.bham.ac.uk/1504/1/JacksonandFleischer_Religion_and_Economics.pdf

Marx, K. (1843). A Contribution to the Critique of Hegel's Philosophy of Right. Retrieved from: https://www.marxists.org/archive/marx/works/1843/cri tique-hpr/intro.htm 
Norcia, M., \& Rissotto, A. (2013). How Religious Faith Affects Beliefs on Poverty: A Study in Italy. International Journal of Social Science and Humanity, 3(2), $180-185$.

Norris, P., \& Inglehart, R. (2004). Sacred and Secular: Religion and Politics Worldwide. Cambridge, UK: Cambridge University Press.

Rees, T.J. (2009). Is Personal Insecurity a Cause of CrossNational Differences in the Intensity of Religious Belief? Journal of Religion and Society, 11, 1-24.

Ruck, D.J., Bentley, R.A., \& Lawson, D.J. (2018). Religious change preceded economic change in the 20th century. Science Advances, 4(7). Retrieved from: http://advances.sciencemag.org/content/advances/4/7/e aar8680.full.pdf

Wiseman, T., \& Young, A. (2014). Religion: Productive or unproductive? Journal of Institutional Economics, 10(1), 21-45.

Yusof, S.A., Budiman, M.A., \& Amin, R.M. (2018). Relationship between Religiosity and Individual Economic Achievement: Evidence from South Kalimantan, Indonesia. Journal of King Abdulaziz University: Islamic Economics, 31(2), 3-16. 


\section{Appendix}

\subsection{Slicing by Multidimensional Poverty}

Are faith deprivation series statistically different in their means conditional on MSI-Poverty?

Is the mean level of faith deprivation among the Multidimensional-Poor group different from that of Multidimensional-NonPoor group?

Table (A1) Criteria for Assessment

\begin{tabular}{|c|c|c|}
\hline MD Status & Multidimensional Poor (MD-Poor) & Multidimensional Non-Poor (MD-Non-Poor \\
\hline \multirow{4}{*}{ 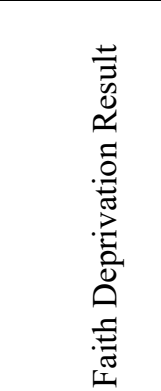 } & mwfaith1 = faith deprivation of MD-Poor & mwfaith $0=$ faith deprivation of MD-Non-Poor \\
\hline & & \\
\hline & \multicolumn{2}{|c|}{$\begin{array}{l}\text { If mean of faith deprivation of MD-Poor }>\text { Mean of faith deprivation of MD-Non-Poor } \\
\text { Then, MD-Poor are more non-religious than MD-Non-Poor. }\end{array}$} \\
\hline & \multicolumn{2}{|c|}{$\begin{array}{l}\text { If mean of faith deprivation of MD-Poor }<\text { Mean of faith deprivation of MD-Non-Poor } \\
\text { Then, MSI-Poor are more religious than MSI-Non-Poor. }\end{array}$} \\
\hline
\end{tabular}

Table (A2) Sample Means of Faith Deprivation of MD-Poor and MD-Non-Poor Groups

\begin{tabular}{|c|c|c|c|c|c|}
\hline Variable & Observation & Mean & Std. Dev. & Min. & Max. \\
\hline wfaith1 & 28858 & 0.095348 & 0.062133 & 0 & 0.2 \\
\hline wfaith0 & 45184 & 0.081321 & 0.063678 & 0 & 0.2 \\
\hline
\end{tabular}

Test of Difference in Means

. ttest wfaith1 $=$ wfaith 0 , unpaired

Two-sample $t$ test with equal variances

\begin{tabular}{lrrrrrr}
\hline Variable & Observation & \multicolumn{1}{c}{ Mean } & Std. Err. & Std. Dev. & \multicolumn{1}{l}{ [95\% Conf. } \\
Interval] & \\
\hline wfaith1 & 28858 & 0.095348 & 0.000366 & 0.062133 & 0.094631 & 0.096065 \\
wfaith0 & 45184 & 0.081321 & 0.0003 & 0.063678 & 0.080734 & 0.081908 \\
& & & & & & \\
Combined & 74042 & 0.086788 & 0.000233 & 0.06345 & 0.086331 & 0.087245 \\
& & & & & & \\
Difference & & 0.014027 & 0.000475 & & 0.013095 & 0.014959
\end{tabular}

Notes:

diff $=$ mean $($ wfaith 1$)-$ mean $($ wfaith 0$)$

$t=29.5095$, Ho: diff $=0$, degrees of freedom $=74040$

Ha: diff $<0$

Ha: $\operatorname{diff} !=0$

Ha: $\operatorname{diff}>0$

$\operatorname{Pr}(T<t)=1.0000$
$\operatorname{Pr}(T>t)=0$
$\operatorname{Pr}(T>t)=0.0000$ 
Table (A3) Number of Respondents by Country

\begin{tabular}{|c|c|c|c|c|c|}
\hline Country & $\begin{array}{l}\text { Number of } \\
\text { Respondents in } \\
\text { stable-age } \\
\text { group (age } 24 \\
\text { to 56) }\end{array}$ & $\begin{array}{l}\text { Total Respond- } \\
\text { ents }\end{array}$ & Country & $\begin{array}{l}\text { Number of } \\
\text { Respondents in } \\
\text { stable-age } \\
\text { group (age } 24 \\
\text { to 56) }\end{array}$ & Total Respondents \\
\hline Algeria & 783 & 1,200 & Palestine & 682 & 1,000 \\
\hline Armenia & 656 & 1,100 & Peru & 752 & 1,210 \\
\hline Australia & 711 & 1,477 & Philippines & 815 & 1,200 \\
\hline Azerbaijan & 697 & 1,002 & Poland & 520 & 966 \\
\hline Belarus & 939 & 1,535 & Qatar & 787 & 1,060 \\
\hline Chile & 616 & 1,000 & Romania & 848 & 1,503 \\
\hline China & 1,528 & 2,300 & Russia & 1,492 & 2,500 \\
\hline Colombia & 966 & 1,512 & Rwanda & 1,234 & 1,527 \\
\hline Cyprus & 606 & 1,000 & Singapore & 1,198 & 1,972 \\
\hline Ecuador & 749 & 1,202 & Slovenia & 600 & 1,069 \\
\hline Egypt & 1,063 & 1,523 & South Korea & 814 & 1,200 \\
\hline Estonia & 811 & 1,533 & Spain & 702 & 1,189 \\
\hline Germany & 1,127 & 2,046 & Sweden & 564 & 1,206 \\
\hline Ghana & 911 & 1,552 & Taiwan & 720 & 1,238 \\
\hline Iraq & 847 & 1,200 & Trinidad & 570 & 999 \\
\hline Japan & 1,309 & 2,443 & Tunisia & 759 & 1,205 \\
\hline Jordan & 792 & 1,200 & Turkey & 1,149 & 1,605 \\
\hline Kazakhstan & 1,054 & 1,500 & Ukraine & 856 & 1,500 \\
\hline Kuwait & 1,032 & 1,303 & United States & 1,231 & 2,232 \\
\hline Kyrgyzstan & 1,078 & 1,500 & Uruguay & 571 & 1,000 \\
\hline Lebanon & 801 & 1,200 & Uzbekistan & 1,073 & 1,500 \\
\hline Libya & 1,574 & 2,131 & Yemen & 735 & 1,000 \\
\hline Malaysia & 936 & 1,300 & Zimbabwe & 1,022 & 1,500 \\
\hline Mexico & 1,339 & 2,000 & & & \\
\hline Morocco & 897 & 1,200 & Total & 46,941 & 74,042 \\
\hline Netherlands & 914 & 1,902 & Minimum & 463 & 841 \\
\hline New Zealand & 463 & 841 & Maximum & 1574 & 2,500 \\
\hline Nigeria & 1,177 & 1,759 & Median & 847.5 & 1269 \\
\hline Pakistan & 871 & 1,200 & & & \\
\hline
\end{tabular}


Salman Syed Ali is Lead Economist at the Islamic Research and Training Institute (IRTI), Islamic Development Bank (IDB). His work focuses on multiple areas of Islamic finance and Islamic economics. He also held the position of Visiting Fellow in Islamic Finance at OCIS, Oxford University (2016-17). Prior to joining IDB, he served as the Director of Research \& Director of Training at the International Institute of Islamic Economics (IIIE), International Islamic University Islamabad (IIUI). He holds a B.Sc. (Hons) in Economics from the International Islamic University, Islamabad, Pakistan and a PhD from the University of Pennsylvania, U.S.A. His areas of interest are Islamic finance, capital markets and game theory. He has a number of research articles and publications to his credit. He has also organized and moderated sessions in a large number of major international conferences. He has represented the IDB in the Technical Committee and various Working Groups of the Islamic Financial Services Board. He is currently the editor of IRTI's journal, Islamic Economic Studies. At IRTI, he has led many research projects for IDB and for other international organizations, contributed in various key development initiatives, and policy reports for the progress of Islamic economics and finance. Currently, he is leading the research cluster on maqāsid al-Sharīah based Socio-economic Development and contributing to the Islamic Financial Development research and training at IRTI.

E-mail: ssyedali@isdb.org

Hamid Hasan is currently Assistant Professor and the Head of School of Economics at the International Islamic University, Islamabad. His teaching and research interests are: applied econometrics, microeconomics, macroeconomics, welfare economics, Islamic economics, energy economics, happiness economics, experimental economics, labor economics, discreet choice economic modelling, behavioral economics, and impact evaluation. He completed his $\mathrm{PhD}$ on Welfare Economics, from School of Business and Law, La Trobe University, Melbourne, Australia. He has also worked as Research Consultant, at the Islamic Research and Training Institute (IRTI), Islamic Development Bank (IBD), Jeddah, Saudi Arabia. Earlier, he taught on deputation, at the School of Economics, King Faisal University, Al-Ahsaa, Kingdom of Saudi Arabia and at the School of Economics and Finance, La Trobe University, Melbourne, Australia. He has a number of publications to his credit and has attended several international conferences.

E-mail: hamidiiiephd@yahoo.co.uk 


\title{
هل يؤثر التدين على الفقر متعدد الأبعاد؟ أدلة من المسح العالمي للقيم (2014-2010م)
}

\author{
سلمان سيد علي

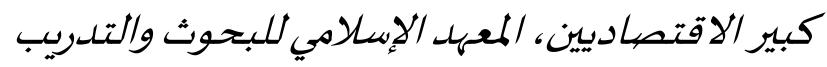 \\ البنك الإسامي للتنمية، جلدة، المملكة العربية السعودية

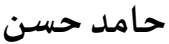 \\ أستاذ مساعلد، المعهيد العالمي للاقتصياد الإسبامي \\ الجامعة الإسلامية العالمية - إسلام أباد، باكستان
}

المستخلص. يوجد انطباع عام بأن التدين يساهم في الفقر انطلاقا من الملاحظات على المستوى الكلي

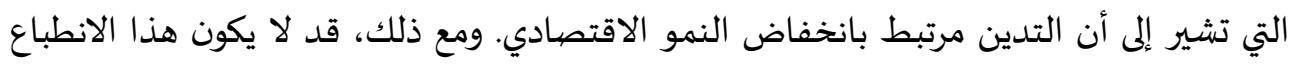

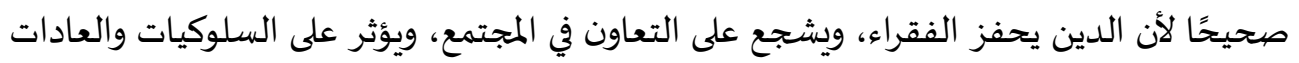
بطرق قد تساعد على الحدد من الفقر. ويستخدم هذا البحث بيانات المسيح العالمي للقيم الذي شمل 52 دولة و 74،042 فردًا، لإنشاء مقياسٍ للفقر متعدد الأبعاد قائمٍ على مؤشر الحرمان، ومقياسٍ للتدين

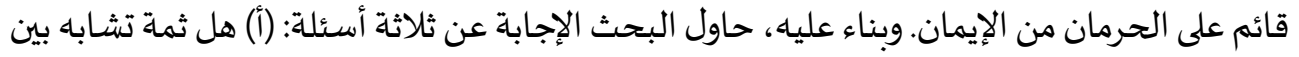

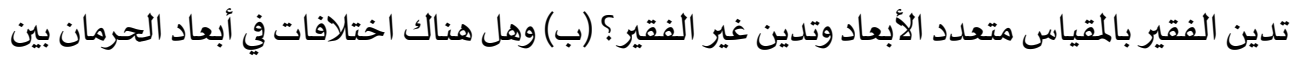
الأشخاص الأكثر تدينا في مقابل الأقل تديناً؟ (ج) وما تأثير التدين على الفقر متعدد الأبعاد؟ وقد التدادي

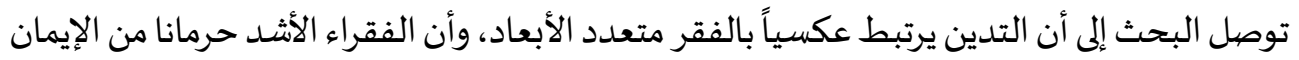

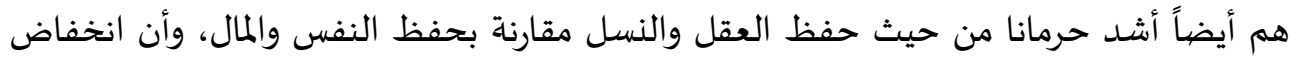

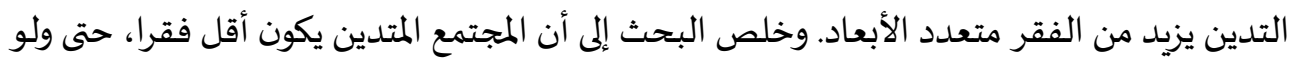
كان نموه الاقتصادي بطيئًا. الكلمات الدَّالة: الدين، مقاصيد الشريعة، الفقر، الفقر متعدد الأبعاد، التدين. تصنيف N30, Z12 : JEL تصنيف:B5, H47, N5: KAUJIE 